\title{
The influence of calf rearing methods and milking methods on performance traits of crossbred dairy cattle in Thailand
}

\section{Milk yield and udder health}

\begin{abstract}
Forty crossbred (75-87.5\% HF) dairy cows were included in a 2 x 2 factorial experiment composed of hand milking (HM) or machine milking (MM), and artificial rearing (bucket feeding, BR) or restricted suckling (RS). Calf suckling and milk feeding was done until 84 days postpartum. Milking was continued until the end of lactation. MM cows had a significantly $(\mathrm{p}<0.05)$ higher daily saleable milk production (SMP) (7.49 vs. 6.97 $\mathrm{kg}$ /day), daily total milk production (TMP) (8.60 vs. $7.96 \mathrm{~kg} /$ day) and total lactation milk yield (TLMY) (2297.72 vs. $2137.41 \mathrm{~kg})$ than HM cows. The RS cows had a significantly $(\mathrm{P}<0.001)$ higher TLMY (2455.46 vs. $1979.68 \mathrm{~kg}$ ), annual total milk yield (ATMY) (2277.23 vs. $1970.73 \mathrm{~kg}$ ), lactation saleable milk yield (LSMY) (2165.90 vs. $1724.64 \mathrm{~kg}$ ), annual saleable milk yield (ASMY) (2035.21 vs. $1721.17 \mathrm{~kg}$ ) and daily saleable milk production (SMP) (7.98 vs. $6.47 \mathrm{~kg} /$ day) than the BR cows. The MM cows showed a significantly $(\mathrm{p}<0.001)$ higher somatic cell score (SCS) than their HM herdmates throughout the study period. The BR cows exhibited a significantly $(\mathrm{p}<0.001)$ higher SCS than RS cows.
\end{abstract}

Key Words: Holstein-Friesian crossbred, total lactation milk yield, restricted suckling, daily saleable milk production, somatic cell score

\section{Zusammenfassung}

Titel der Arbeit: Leistungseigenschaften bei Kreuzungs-Milchkühen in Thailand. 1. Mitt.: Milchleistung und Eutergesundheit

40 Kreuzungskühe (75 - 87,5 \% Holstein-Friesen) wurden in einem 2 x 2 faktoriellen Experiment mit den Behandlungen Handmelken (HM) und Maschinenmelken (MM), sowie der Tränkekälberaufzucht (BR) oder dem partiellen Säugen (RS) zugeordnet. Kälber wurden im Alter von 84 Tagen post partum abgesetzt. Alle Kühe wurden bis zum natürlichen Ende der Laktation gemolken. MM Kühe hatten eine signifikant $(\mathrm{p}<0,05)$ höhere tägliche verkaufbare Milchmenge (SMP) (7,49 vs. 6,97 kg/Tag), eine tägliche Gesamtmilchmenge (TMP) (8,60 vs. 7,96 kg/Tag) und eine Gesamtlaktationsmilchleistung (TLMY) (2297,72 vs. 2137,41 kg) als handgemolkene Kühe. Kühe der partiellen Säugegruppe (RS) hatten eine signifikant $(p<0,001)$ höhere TLMY (2455,46 vs. 1979,68 kg), Gesamtjahresmilchleistung (ATMY) (2277,23 vs. 1970,73 kg), verkaufbare Laktationsmilchleistung (LSMY) (2165,90 vs. 1724,64 kg), verkaufbare Jahresmilchleistung (ASMY) (2035,21 vs. 1721,17 kg) und tägliche verkaufbare Milchleistung (SMP) (7,98 vs. 6,47 kg/Tag) als Kühe ohne partielles Säugen ihrer Kälber. Die MM-Gruppe hatte eine signifikant höhere Zellzahl als die Kühe der HM-Gruppe während der gesamten Untersuchungsperiode. Bei Kühen mit partiellem Säugen der Kälber konnte eine signifikant $(p<0,001)$ geringere Zellzahl als bei Kühen ohne Säugen festgestellt werden.

Schlüsselwörter: Holstein-Friesen Kreuzungskühe, Gesamtlaktationsmilchleistung, partielles Kälbersäugen, tägliche verkaufbare Milchmenge, Zellzahl

\section{Introduction}

The Thai government since 1977 has followed a policy to attain self-sufficiency in milk production and to increase milk consumption. Between 1991 and 1996 dairy cattle numbers have increased from 102,717 heads to 167,181 heads and milk 
production from 164,340 t to 380,101 tons. However, total production of raw milk still meets only about 30-40 \% of the domestic consumption demand (CHANTALAKHANA, 1995).

Machine milking and bucket rearing of calves is propagated in dairy enterprises and small holder dairies. The majority of Thai dairy cattle are crossbreds between Local and Holstein Friesian. Average milk yield of a crossbred cow is $8-10 \mathrm{~kg} / \mathrm{head} /$ day or 2700-3000 kg/lactation with a lactation period of up to 300 days. A serious problem is the high rate of mastitis in dairy herds (POLPAK, 1994a; VINTHER, 1974). POLPAK (1994b) reported $58.6 \%$ of mastitis cases in dairy cattle under smallholder management. Though the economic loss was not reported, most of the mastitis cows were culled from herds. Thus, alternative husbandry practices to improve efficiency in dairying need to be tested and their effects on cow performance evaluated.

This paper reports results of a study conducted to evaluate the effect of calf rearing management and milking method on milk production and udder health of cows.

\section{Materials and methods}

The experiment was conducted from February 1997 to October 1998 at Ubon Ratchathani University, Ubon Ratchathani province, Thailand. The 40 experimental cows had a $75 \%$ and $87.5 \%$ HF upgrade level and were inseminated with samen of $100 \%$ HF purebred and 75 \% HF bulls to produce calves with 87.5 and $81.25 \%$ HF gene proportion. Cows were arranged into a $2 \times 2$ factorial experiment with two calf rearing treatments: bucket rearing (BR) twice daily between day 4-84 postpartum and restricted suckling (RS) for 15 minutes after each milking time, twice daily between day 4-84 postpartum) and with hand milking (HM) and machine milking (MM) twice daily. The experiment started at day 4 postpartum and ended when the average daily yield of a cow during a full week did not exceed $2 \mathrm{~kg}$.

Lactating cows were kept day and night in-house from calving to day 84 post calving, and from day 85 until the end of lactation on pasture during daytime and in-house during night time. The shed had a concrete floor and was well ventilated. The cows grazed a grass-legume pasture composed of Brachiaria ruziziensis (Ruzi) grass and Stylosanthes hamata legume during 6.30-15.30 hr. and they received a yield dependent concentrate supplementation according to NRC (1989) recommendations. The cows received ad libitum access to water and a mineral block both in the shed and on pasture.

During the first three days postpartum all calves were allowed to suckle freely. From the fourth day of lactation milking was done at 5.30 and 16.00 , respectively.

The udder of all experimental cows were washed with $0.5 \%$ Iodophor solution and dried with a cotton cloth before milking and teats were dipped after milking with 0.5 \% Iodophor. Each animal had a separate cloth. In the case of RS, the udder was washed with clean water and dried before suckling. Post-suckling, the teats were dipped with $0.5 \%$ Iodophor again.

\section{Data collection}

Data were collected using prepared forms for the following traits:

1) Daily milk yield of the cows

2) Milk consumption by calves 
3) Chemical composition of milk sample

4) Somatic cell count data

Milk yield was recorded daily. Milk intake by calves was determined every second day through the weigh-suckle-weigh method.

Milk yield was measured at each milking and computed to the following yield traits:

daily SMP = milked-out volume minus amount of milk bucket fed to calf (2.9 $\mathrm{kg} /$ day)

daily TMP $=$ milked-out volume plus amount milk suckled by calf $(3.36 \mathrm{~kg} / \mathrm{day})$

TLMY $=$ total milked-out volume from the $4^{\text {th }}$ day until the end of lactation plus total amount of suckled milk during day 4-84 post partum

ATMY $\quad=$ annual total milk yield $=$ TLMY $\times 365 \times$ calving interval $^{-1}$

SLMY $=$ Total milked-out volume from the $4^{\text {th }}$ day until the end of lactation minus total amount of milk bucket fed to calf during day 4-84 post partum

Chemical composition of milk was determined every four weeks. $150 \mathrm{~g}$ of milk was collected in a screw cap flask containing $0.15 \mathrm{~g}$ of measures chloride-potassium dichromate as preserver (AOAC, 1984). Samples were collected from the fore, medium and residual milking phase. Fat, protein and solids not fat (SNF) were determined by the "Forsometric Milko Scan Model S500" (Foss Electric, Denmark) The somatic cell count (SCC) was done every two weeks on the morning foremilk from each quarter, starting the second week until week 36 of lactation. The number of somatic cells in milk samples was determined within 48 hours by the Prescott and Breed microscopic cell count method as described by AOAC (1984). The number of counted cells was transformed to a somatic cell score (SCS) as described by GOODWIN and SPELMAN (1994). The transformation data were the geometric mean of the log-transformed SCC and were calculated using the following equation:

$$
\mathrm{SCS}=3+\log _{2}(\mathrm{SCC} / 100,000)
$$

Data analysis

The SAS procedure for General Linear Models (GLM) of the Statistical Analysis System Release 6.12 (SAS, 1998) was used for the analysis of variance. The following linear models were used for the different traits. Daily saleable milk production (daily SMP), daily total milk production (daily TMP), total lactation milk yield (TLMY), annual total milk yield (ATMY), salable lactation milk yield (SLMY), annual salable milk yield (ASMY).

Model 1: Daily SMP, daily TMP, TLMY, ATMY, SLMY, ASMY, and lactation length.

$Y_{i j}=\mu+M_{i}+C_{j}+P_{k}+G_{l}+e_{i j k l}$

Model 2: Milk fat, protein and SNF content.

$\mathrm{Y}_{\mathrm{ijklmno}}=\mu+\mathrm{M}_{\mathrm{i}}+\mathrm{C}_{\mathrm{j}}+\mathrm{P}_{\mathrm{k}}+\mathrm{G}_{\mathrm{l}}+\mathrm{S}_{\mathrm{m}}+\mathrm{POR}_{\mathrm{n}}+\mathrm{W}_{\mathrm{o}}+\mathrm{MW}_{\mathrm{io}}+\mathrm{CW}_{\mathrm{jo}}+\mathrm{e}_{\mathrm{ijklmno}}$

Model 3 : Somatic cell score (SCS).

$\mathrm{Y}_{\mathrm{ijkl}}=\mu+\mathrm{M}_{\mathrm{i}}+\mathrm{C}_{\mathrm{j}}+\mathrm{P}_{\mathrm{k}}+\mathrm{G}_{\mathrm{l}}+\mathrm{S}_{\mathrm{m}}+\mathrm{POR}_{\mathrm{n}}+\mathrm{W}_{\mathrm{o}}+\mathrm{Q}_{\mathrm{p}}+\mathrm{MW}_{\mathrm{io}}+\mathrm{CW}_{\mathrm{jo}}+\mathrm{e}_{\mathrm{ijklmnop}}$ 
Where

$\begin{array}{lll}\mathrm{M} & = & \text { Milking method } \\ \mathrm{C} & = & \text { Calf rearing system } \\ \mathrm{P} & = & \text { Parity number } \\ \mathrm{G} & = & \text { HF gene proportion } \\ \mathrm{S} & = & \text { Season at calving } \\ \mathrm{POR} & = & \text { Portion of milk sample } \\ \mathrm{W} & = & \text { Week of lactation } \\ \mathrm{Q} & = & \text { Quarter } \\ \mathrm{M} \times \mathrm{W} & = & \text { Interaction milking method } \mathrm{x} \text { week of lactation } \\ \mathrm{C} \times \mathrm{W} & = & \text { Interaction calf rearing method } \mathrm{x} \text { week of lactation }\end{array}$

Results

Overall lactation performance

Daily milk production

A major effect on daily saleable milk production (SMP) was caused by the calf rearing management with a significant larger SMP in cows exposed to restricted suckling (RS calf rearing) compared to non suckled cows (Bucket calf rearing, BR) throughout the study period (Table 1). Of special interest is the additional SMP of $3.08 \mathrm{~kg} /$ day during the first 3 months of lactation of cows under the RS management. As illustrated in Figure 1, RS cows had a higher daily SMP than BR cows by $46.50 \%$ and $11.83 \%$ during the first 12 weeks and between $12^{\text {th }}$ to $36^{\text {th }}$ week of lactation, respectively,

Table 1

Least squares means of daily saleable milk production (SMP) and daily total milk production (TMP) of the cows (LSQ-Mittel der täglichen verkaufbaren Milchmenge (SMP) und der täglichen Gesamtmilchmenge (TMP) der Kühe)

\begin{tabular}{|c|c|c|c|c|c|}
\hline \multirow{2}{*}{ Main effects } & \multirow{2}{*}{$\mathrm{n}$} & \multicolumn{2}{|c|}{ Average daily SMP (kg/day) } & \multicolumn{2}{|c|}{ Average daily TMP (kg/day) } \\
\hline & & Day 4-84 & Day 85-252 & Day 4-84 & Day 85-252 \\
\hline Calf rearing & & $* * *$ & $* *$ & $* * *$ & $* *$ \\
\hline Bucket rearing & 20 & $6.75 \pm 0.24$ & $6.34 \pm 0.18$ & $9.70 \pm 0.25$ & $6.40 \pm 0.18$ \\
\hline Restricted suckling & 20 & $9.83 \pm 0.24$ & $7.09 \pm 0.18$ & $13.19 \pm 0.25$ & $7.11 \pm 0.18$ \\
\hline Milking method & & $* *$ & ns & $* * *$ & ns \\
\hline Hand & 20 & $7.76 \pm 0.24$ & $6.58 \pm 0.18$ & $10.79 \pm 0.25$ & $6.60 \pm 0.18$ \\
\hline Machine & 20 & $8.81 \pm 0.24$ & $6.85 \pm 0.18$ & $12.10 \pm 0.25$ & $6.91 \pm 0.18$ \\
\hline Parity number & & $* * *$ & $* *$ & $* *$ & $* *$ \\
\hline First & 16 & $7.65 \pm 0.26$ & $6.30 \pm 0.20$ & $10.86 \pm 0.28$ & $6.31 \pm 0.20$ \\
\hline Second or third & 24 & $8.99 \pm 0.22$ & $7.13 \pm 0.16$ & $12.03 \pm 0.23$ & $7.19 \pm 0.16$ \\
\hline HF gene proportion & & $*$ & ns & ns & ns \\
\hline $75.0 \%$ & 21 & $7.93 \pm 0.23$ & $6.60 \pm 0.18$ & $11.12 \pm 0.25$ & $6.63 \pm 0.17$ \\
\hline $87.5 \%$ & 19 & $8.64 \pm 0.24$ & $6.83 \pm 0.19$ & $11.77 \pm 0.26$ & $6.87 \pm 0.18$ \\
\hline $\mathrm{n}$ & & 40 & 40 & 40 & 40 \\
\hline $\mathrm{R}^{2}$ & & 0.76 & 0.34 & 0.38 & 0.61 \\
\hline CV (\%) & & 12.58 & 13.30 & 11.80 & 11.03 \\
\hline Mean \pm sem & & $8.29 \pm 0.17$ & $8.20 \pm 0.18$ & $6.79 \pm 0.13$ & $7.23 \pm 0.13$ \\
\hline LSQ Mean & & 8.29 & 6.72 & 11.44 & 6.76 \\
\hline
\end{tabular}


which clearly indicates the prolonged effect of partial suckling beyond the weaning time.

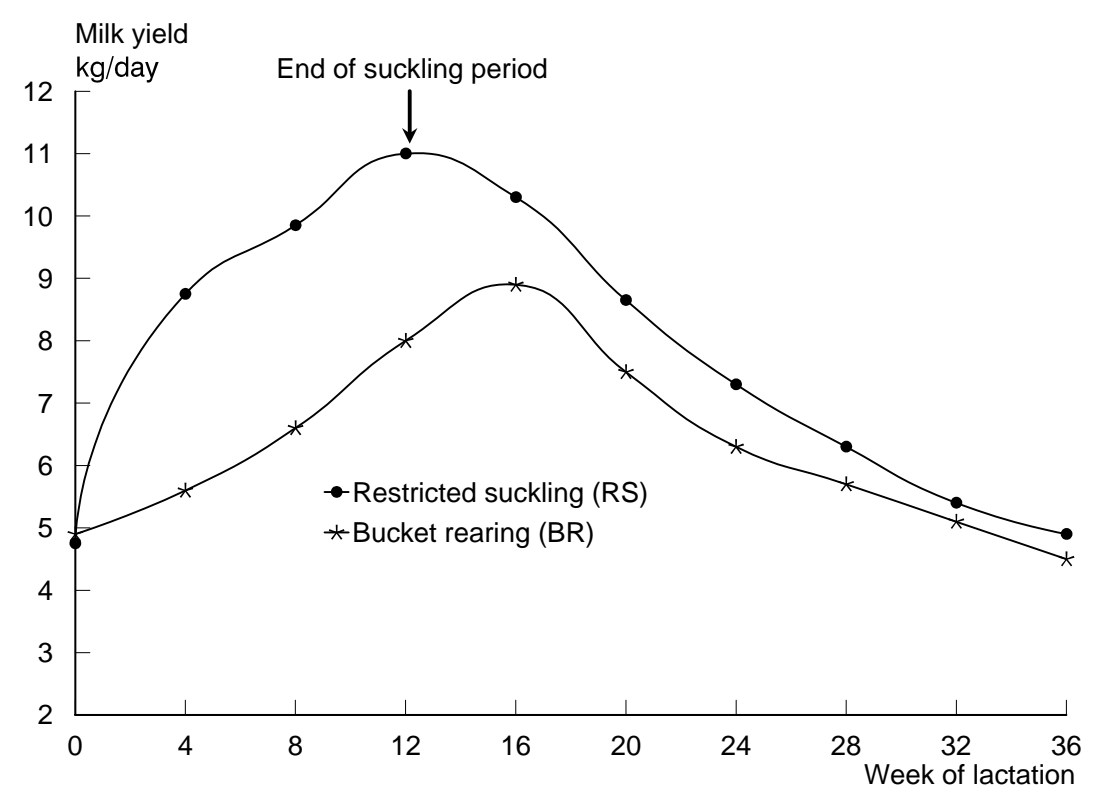

Fig. 1: Effect of calf rearing management on daily saleable milk production (SMP) during 36 weeks of lactation (BR = bucket rearing system, RS = restricted suckling system) [Einfluss des Aufzuchtverfahrens auf die tägliche verkaufbare Milchmenge (SMP) während 36 Laktationswochen (BR = Tränkekälberaufzucht, RS = partielles Säugen)]

The milking method influenced daily SMP only during day 4-84 $(\mathrm{p}<0.01)$ of lactation, but not thereafter. Cows of the machine-milking group had a significantly higher daily SMP than those being hand-milked.

As expected, parity number of the cows had also a significant effect on daily SMP throughout the period of the study. Multiparous cows significantly exceeded primiparous cows in SMP by 12.16-16.21 \%. With respect to HF genotype, it was found that the $87.5 \%$ crossbred cows had a significantly $(\mathrm{p}<0.05)$ higher daily SMP than the $75.0 \%$ crossbred cows during the period of day 4-84 of lactation. For the latter part of lactation the effect was not significant (Table 1).

Machine-milking yielded a significantly $(\mathrm{p}<0.001)$ higher total milk production (TMP) than hand milking only during day 4-84, with a difference from the hand-milking group of $1.3 \mathrm{~kg}$ or $12.1 \%$ daily.

The calf rearing system and milking method had significant effects on daily TMP (Table 1). Cows of the suckling group (RS) had a significantly $(\mathrm{p}<0.01$ or $\mathrm{p}<0.001)$ better daily TMP than the non-suckled group (BR) throughout the study period. It was found that the daily TMP of RS cows exceeded the BR cows by $3.49 \mathrm{~kg}$ (35.98 \%) and by $0.71 \mathrm{~kg}$ (11.09\%), during the periods of day 4-84 and day 85-252 of lactation, respectively (Table 1 ).

\section{Overall lactation performance (TLMY)}

The overall milk performance of experimental cows is expressed as the cumulative total lactation milk yield (TLMY), the annual total milk yield (ATMY), and as the saleable lactation milk yield (SLMY).

All main effects significantly affected the TLMY yield, which had an overall mean of $2235.45 \mathrm{~kg}$. The model explains $68 \%$ of the total variation of this trait (Table 2). 
Cows with restricted suckling (RS) attained a highly significantly improved TLMY and ATMY, with a difference of $24.03 \%$ and $15.55 \%$, resp. over non suckled cows (BR).

Restricted suckling of cows also led to a significant higher LSMY $(\mathrm{p}<0.001)$ and ASMY $(\mathrm{p}<0.05)$ with a $25.59 \%$ and $18.25 \%$ advantage over cows without suckling. It is also noteworthy that RS cows exhibited a higher TLMY per day of calving interval than non suckled cows.

The milking method treatment failed to significantly affect the ATMY, although machine-milking again led to higher yields.

In this study, the earliest drying off date was at day 252 of lactation and the latest drying-off date occurred at day 377 of lactation. It was found that $2.5 \%$ of cows were dried off at the $252^{\text {nd }}$ day, $25.0 \%$ during day 253-280, $50.0 \%$ during day 281-308 and $22.5 \%$ during period 309-377 days of lactation. Results in Table 2 indicate that cows exposed to restricted suckling during day 4-84 of lactation exhibited a highly significantly $(\mathrm{p}<0.001)$ longer lactation period (307.34 days) than non suckled cows (283.80 days). The milking method had no influence on lactation lengths.

\section{Table 2}

Least squares means of total lactation milk yield (TLMY), annual total milk yield (ATMY), lactation saleable milk yield (LSMY) and lactation length of the cows (LSQ-Mittel der Gesamtlaktationsmilchleistung (TLMY), der Gesamtjahresmilchleistung (ATMY), der verkaufbaren Laktationsmilchleistung (LSMY) und der Laktationsdauer der Kühe)

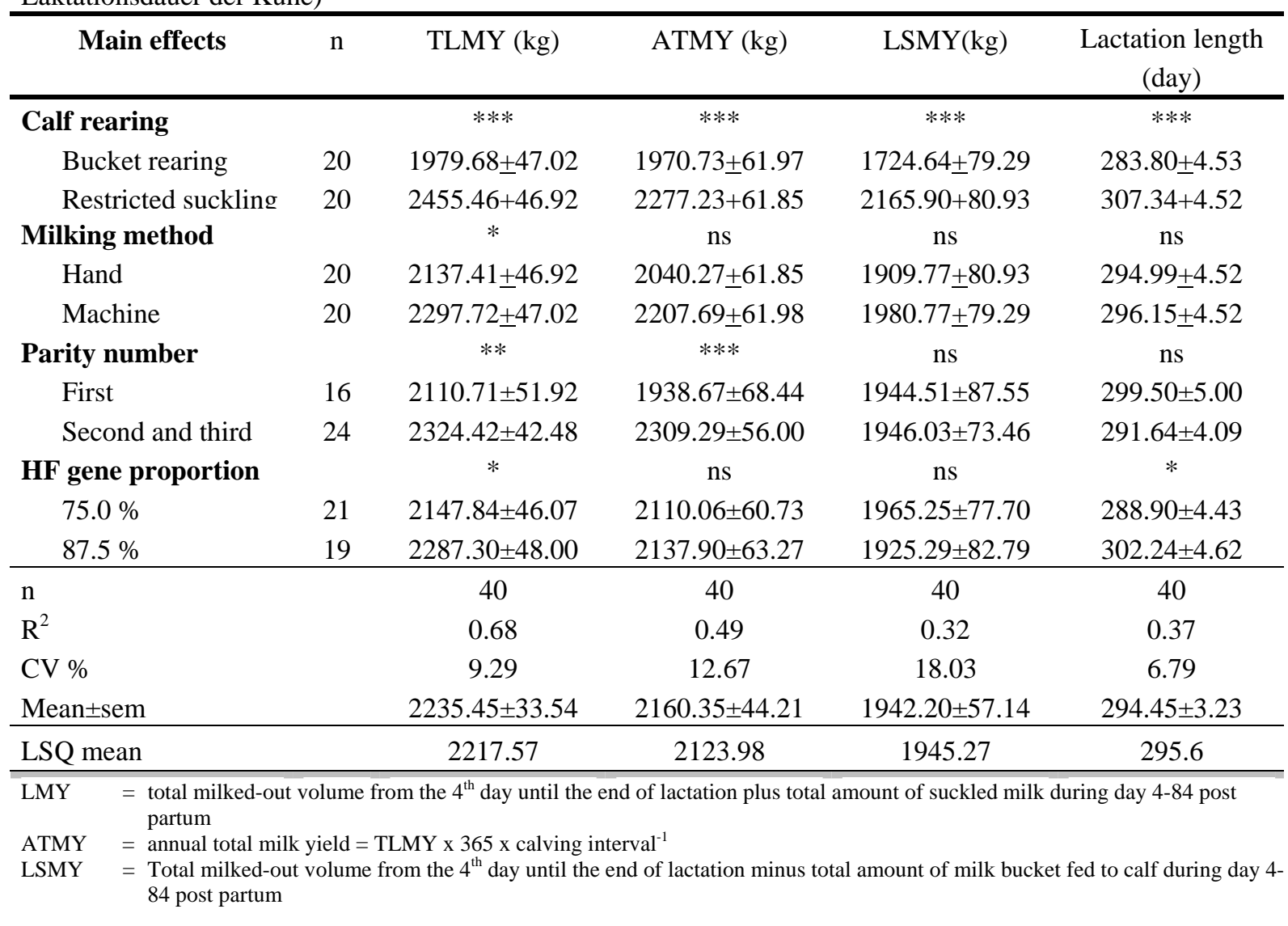

\section{Milk components}

Results of the analysis of variance (GLM) for the main effects and interaction effects on milk components percentage are presented in Table 3. The model explains between 12 and $93 \%$ of variation with a CV between $10.63-13.62 \%$ for various milk 
components (Table 3). Interactions effects milking method x week of lactation and calf rearing method $\mathrm{x}$ week of lactation had no significant effect on milk component traits.

Table 3

Least squares means of the milk components percentage during week 2-36 of lactation (LSQ-Mittel der Milchinhaltsstoffe während der 2.-36. Laktationswoche (in \%))

\begin{tabular}{|c|c|c|c|c|}
\hline Main effects & $\mathrm{n}$ & Milk fat (\%) & Milk protein (\%) & Milk SNF (\%) \\
\hline Calf rearing & & $* *$ & ns & ns \\
\hline Bucket rearing & 600 & $3.65 \pm 0.02$ & $3.22 \pm 0.02$ & $8.61 \pm 0.04$ \\
\hline Restricted suckling & 600 & $3.57 \pm 0.02$ & $3.25 \pm 0.01$ & $8.66 \pm 0.04$ \\
\hline Milking method & & $* * *$ & ns & $* * *$ \\
\hline Hand & 600 & $3.67 \pm 0.02$ & $3.25 \pm 0.01$ & $8.86 \pm 0.04$ \\
\hline Machine & 600 & $3.55 \pm 0.02$ & $3.22 \pm 0.01$ & $8.41 \pm 0.04$ \\
\hline Parity number & & $* * *$ & $* *$ & $* * *$ \\
\hline Primiparous & 480 & $3.72 \pm 0.02$ & $3.27 \pm 0.02$ & $8.72 \pm 0.04$ \\
\hline Multiparous & 720 & $3.50 \pm 0.02$ & $3.20 \pm 0.01$ & $8.54 \pm 0.03$ \\
\hline HF gene proportion & & $* *$ & ns & ns \\
\hline $75.0 \%$ & 630 & $3.65 \pm 0.02$ & $3.24 \pm 0.01$ & $8.64 \pm 0.04$ \\
\hline $87.5 \%$ & 570 & $3.56 \pm 0.02$ & $3.23 \pm 0.02$ & $8.62 \pm 0.04$ \\
\hline Season at calving & & ns & ns & $* * *$ \\
\hline Wet & 660 & $3.61 \pm 0.02$ & $3.22 \pm 0.01$ & $8.42 \pm 0.04$ \\
\hline Dry & 540 & $3.60 \pm 0.02$ & $3.25 \pm 0.02$ & $8.84 \pm 0.04$ \\
\hline Portion of milk sample & & $* * *$ & ns & ns \\
\hline Fore-milk & 400 & $1.53 \pm 0.02^{\mathrm{a}}$ & $3.26 \pm 0.02$ & $8.66 \pm 0.05$ \\
\hline Whole milk & 400 & $3.38 \pm 0.02^{\mathrm{b}}$ & $3.22 \pm 0.02$ & $8.62 \pm 0.05$ \\
\hline Residual milk & 400 & $5.91 \pm 0.02^{\mathrm{c}}$ & $3.22 \pm 0.02$ & $8.61 \pm 0.05$ \\
\hline Week of lactation & & $* * *$ & $* * *$ & $* * *$ \\
\hline $2^{\text {nd }}$ & 120 & $3.69 \pm 0.04^{\mathrm{cd}}$ & $3.24 \pm 0.03^{b}$ & $8.86 \pm 0.08^{\mathrm{c}}$ \\
\hline $6^{\text {th }}$ & 120 & $3.47 \pm 0.04^{\mathrm{b}}$ & $3.07 \pm 0.03^{\mathrm{a}}$ & $8.62 \pm 0.08^{\mathrm{b}}$ \\
\hline $10^{\text {th }}$ & 120 & $3.29 \pm 0.04^{\mathrm{a}}$ & $3.04 \pm 0.03^{\mathrm{a}}$ & $8.33 \pm 0.08^{\mathrm{a}}$ \\
\hline $14^{\text {th }}$ & 120 & $3.39 \pm 0.04^{\mathrm{ab}}$ & $3.12 \pm 0.03^{\mathrm{a}}$ & $8.31 \pm 0.08^{\mathrm{a}}$ \\
\hline $18^{\text {th }}$ & 120 & $3.55 \pm 0.04^{\mathrm{bc}}$ & $3.23 \pm 0.03^{b}$ & $8.45 \pm 0.08^{\mathrm{ab}}$ \\
\hline $22^{\text {nd }}$ & 120 & $3.60 \pm 0.04^{\mathrm{c}}$ & $3.28 \pm 0.03^{\mathrm{bc}}$ & $8.51 \pm 0.08^{\mathrm{ab}}$ \\
\hline $26^{\text {th }}$ & 120 & $3.67 \pm 0.04^{\mathrm{cd}}$ & $3.31 \pm 0.03^{\mathrm{bc}}$ & $8.71 \pm 0.08^{\mathrm{bc}}$ \\
\hline $30^{\text {th }}$ & 120 & $3.78 \pm 0.04^{\mathrm{de}}$ & $3.35 \pm 0.03^{c}$ & $8.84 \pm 0.08^{\mathrm{bc}}$ \\
\hline $34^{\text {th }}$ & 120 & $3.81 \pm 0.04^{\mathrm{e}}$ & $3.34 \pm 0.03^{\mathrm{c}}$ & $8.84 \pm 0.08^{\mathrm{bc}}$ \\
\hline $36^{\text {th }}$ & 120 & $3.82 \pm 0.04^{\mathrm{e}}$ & $3.38 \pm 0.03^{\mathrm{c}}$ & $8.85 \pm 0.08^{\mathrm{c}}$ \\
\hline Interaction effects & $\mathrm{df}$ & & & \\
\hline $\mathrm{M} \times \mathrm{W}$ & 9 & ns & ns & ns \\
\hline $\mathrm{C} \times \mathrm{W}$ & 9 & ns & ns & ns \\
\hline $\mathrm{n}$ & & 1200 & 1200 & 1200 \\
\hline $\mathrm{R}^{2}$ & & 0.93 & 0.12 & 0.16 \\
\hline CV (\%) & & 13.62 & 11.01 & 10.63 \\
\hline Mean \pm sem & & $3.59 \pm 0.02$ & $3.23 \pm 0.01$ & $8.59 \pm 0.03$ \\
\hline
\end{tabular}

$\mathrm{HF}=$ Holstein-Friesian, $\mathrm{SNF}=$ solids not fat, $\mathrm{M}=$ milking method, $\mathrm{C}=$ calf rearing management, $\mathrm{W}$ = week of lactation

ns $=$ non significant, $* *=\mathrm{p}<0.01, * * *=\mathrm{p}<0.001$

$\mathrm{a}, \mathrm{b}, \mathrm{c}, \ldots \mathrm{e}=$ means with different superscripts within column of the same effect differ significantly

Milk nutrient content

Milking method, calf rearing system, parity number of the cow, HF gene proportion and week of lactation all affected milk fat content significantly. Season of calving and interaction effects did not significantly affect this trait. 
Hand-milked cows yielded a highly significantly $(\mathrm{p}<0.001)$ higher milk fat percentage (3.67\%) than their machine-milked herdmates (3.55\%). With regard to calf rearing management, it was found that BR cows had a significantly $(\mathrm{p}<0.01)$ higher average milk fat percentage than the RS cows during the study period (Table 3 ).

Primiparous cows had a significantly $(\mathrm{p}<0.001)$ higher average milk fat percentage than multiparous cows and increased HF gene proportion affected milk fat percentage negatively $(\mathrm{p}<0.01)$. However, the difference in milk fat percentage between $75.0 \%$ $\mathrm{HF}$ and $87.5 \% \mathrm{HF}$ is rather small.

Highly significant differences $(\mathrm{p}<0.001)$ in milk fat content exist between the three milk samples i.e. fore milk, whole milk and residual milk (Table 3 ). The lowest fat percentage was found in the fore-milk, an intermediate amount in whole milk and the highest fat percentage in the residual milk. A distinct pattern of fat content was observed depending on the lactation phase: with a higher fat content during the first week of lactation a lower level during the peak lactation curve and increasing levels towards the end of lactation.

This changing pattern of milk fat content is useful for the explanation of the nutrient consumption of the calves.

Milk protein content was not affected by the two treatments: milking method and calf rearing method. The only significant affect was related to parity number with a slight advantage of primiparous cows.

During the initial phase of lactation the protein content decreased from 3.24 to 3.04 and then increased during the middle phase continuously up to 3.38 during the final lactation week.

The SNF content was affected by milking method, parity number of the cow, season at calving and week of lactation, but not calf rearing system, and other systematic factors. Hand-milked cows showed a highly significantly $(\mathrm{p}<0.001)$ greater milk SNF percentage than their machine-milked herdmates. Primiparous cows exceeded their multiparous herdmates highly significantly $(\mathrm{p}<0.001)$ and cows which calved in the dry season yielded a significantly $(\mathrm{p}<0.001)$ higher milk SNF percentage than their herdmates that calved in the wet season. Milk SNF percentage was also affected by the stage of lactation and showed the same alteration pattern as milk fat and milk protein and varied between $8.86 \%$ at the $2^{\text {nd }}$ week of lactation, a lowest SNF of 8.31 in the $14^{\text {th }}$ weeks and again increased values up to 8.85 during the end of lactation.

Udder health

Somatic cell count was measured for every individual udder quarter of all 40 cows every week from the second week postpartum until the $252^{\text {nd }}$ week of lactation. Mastitis cases were found in the total incidence of $17.5 \%$ of cows and $6.25 \%$ of all quarters. Left quarters had a higher rate of clinical mastitis than the right quarters (9 vs. 1 udder). A mastitis case was registered if the SCC was higher than 400,000 cells/ml. Quarter position had a highly significant $(\mathrm{p}<0.001)$ influence on SCS of the cows. Week of lactation also significantly $(\mathrm{p}<0.001)$ affected SCS during weeks 2-36 of lactation. The SCS pattern over the lactation period showed a higher SCS during the first lactation period (week 2-4) and during the third lactation period (week 16-36), which can be associated with pattern of the lactation curve.

Restricted suckling led to a highly significant $(\mathrm{p}<0.001)$ lower SCS (Table 4). Up to the $12^{\text {th }}$ week of lactation cows allotted to the RS treatment were allowed to suckle their calves for 15 minutes after each milking time, while the BR cows did not nurse 
their calves which caused a 7-18 \% lower SCS in the former group. After weaning the SCS pattern in both of the BR and RS cows was similar and followed the normal pattern of a slightly increased SCS with lowering milk yield (Fig. 2).

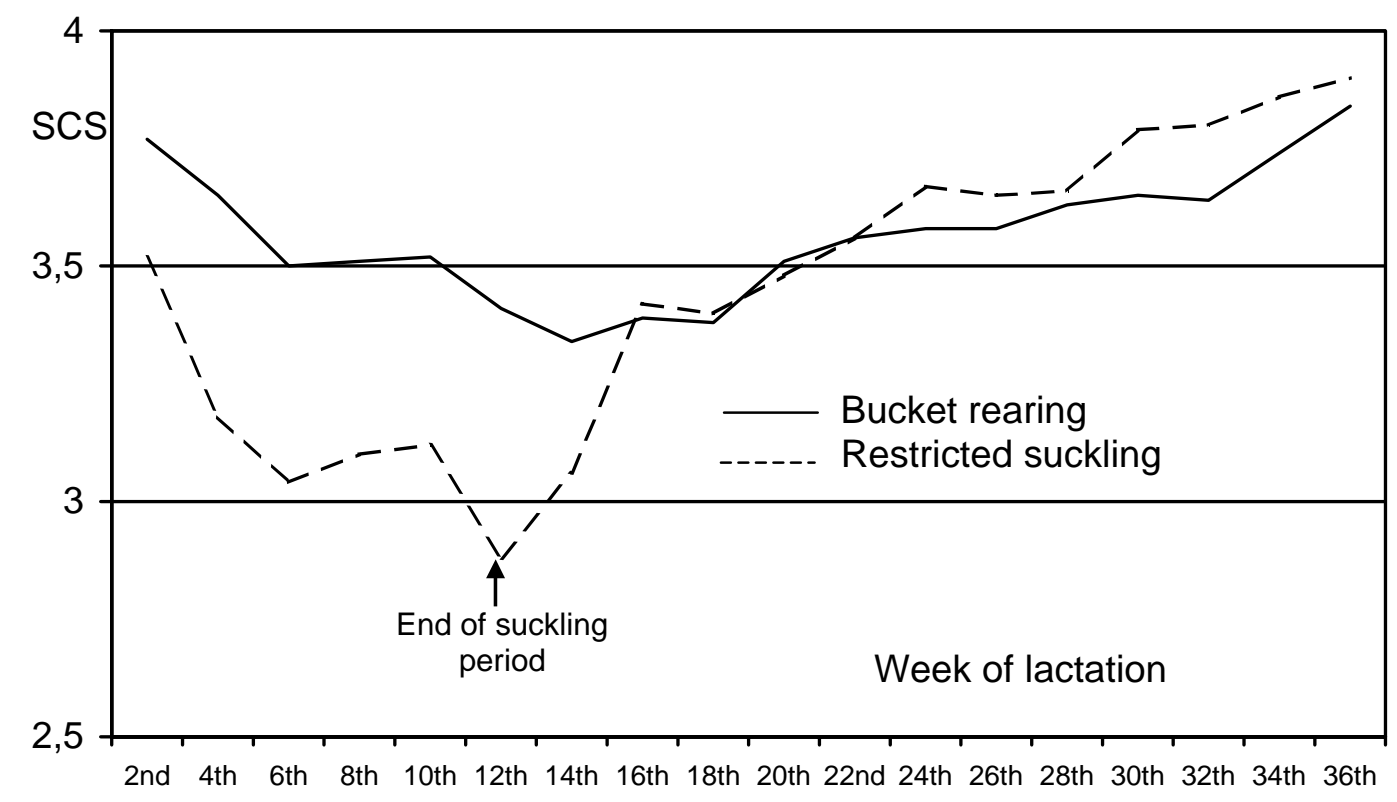

Fig. 2: Effect of restricted suckling and bucket rearing of calves on the SCS during weeks 2-36 of lactation of HF-crossbred cows ( $<<0.001)$ (Einfluss der Kälberfütterung auf die somatische Zellzahl der HF-Kreuzungskühe während der 2.-36. Laktationswoche, $\mathrm{p}<0,001$ )

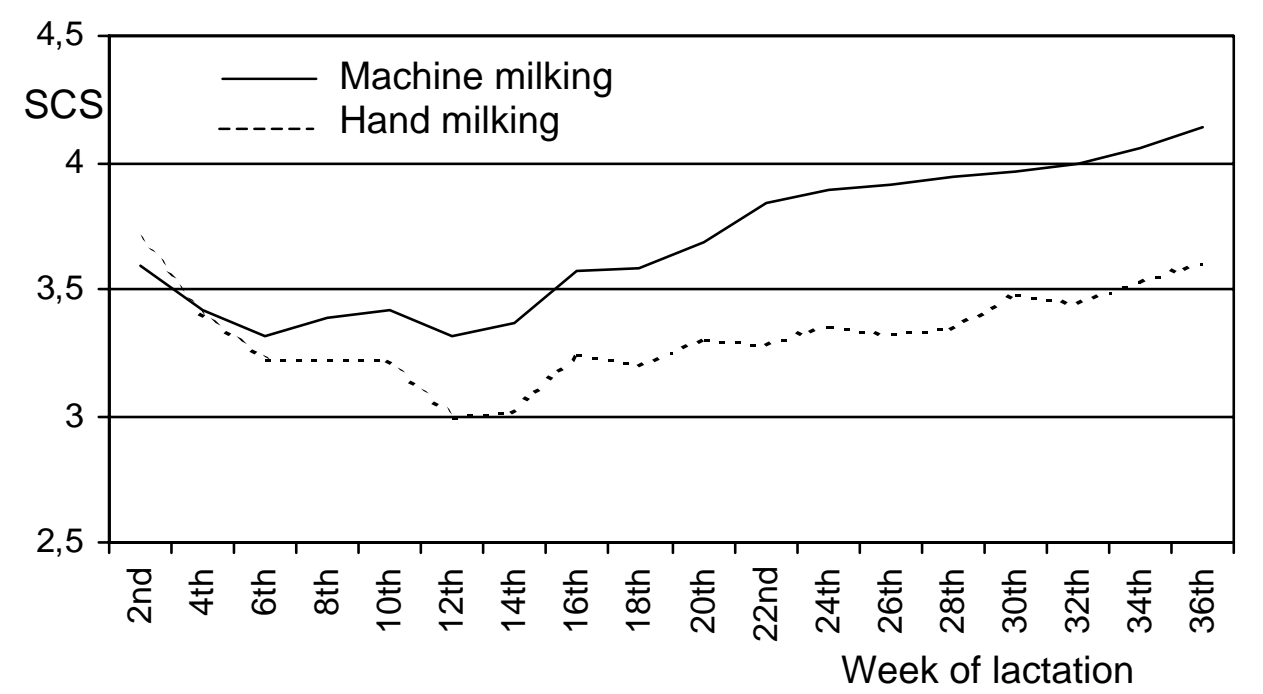

Fig. 3: Effect of milking methods on SCS during weeks 2-36 of lactation of HF-crossbred cows (Einfluss der Melkmethode auf die somatische Zellzahl der HF-Kreuzungskühe während der 2.-36. Laktationswoche)

The milking method caused a highly significant difference in SCS over the lactation period (Fig. 3). During weeks 2-10 of lactation both hand-milked and machine-milked cows exhibited the same pattern of SCS alteration, but, from week 12 until week 36 of lactation results clearly showed a different SCS pattern between the two milking methods causing a 10-18 \% higher SCS in machine milked cows over their hand milked herdmates. 
Table 4

Least squares means of the somatic cell score (SCS) during weeks 2-36 of lactation (LSQ-Mittel der somatischen Zellzahl während der 2.-36. Laktationswoche)

\begin{tabular}{|c|c|c|}
\hline Main effects & $n$ & SCS \\
\hline Calf rearing & & $* * *$ \\
\hline Bucket rearing & 1440 & $3.57 \pm 0.02$ \\
\hline Restricted suckling & 1440 & $3.45 \pm 0.02$ \\
\hline Milking method & & $* * *$ \\
\hline Hand & 1440 & $3.33 \pm 0.02$ \\
\hline Machine & 1440 & $3.69 \pm 0.02$ \\
\hline Quarter & & $* * *$ \\
\hline Left front & 720 & $3.60 \pm 0.02^{\mathrm{a}}$ \\
\hline Right front & 720 & $3.56 \pm 0.02^{\mathrm{a}}$ \\
\hline Left rear & 720 & $3.55 \pm 0.02^{\mathrm{a}}$ \\
\hline Right rear & 720 & $3.33 \pm 0.02^{b}$ \\
\hline Parity number & & $* * *$ \\
\hline Primiparous & 1152 & $3.22 \pm 0.02$ \\
\hline Multiparous & 1152 & $3.80 \pm 0.02$ \\
\hline HF gene proportion & & $* * *$ \\
\hline $75.0 \%$ & 1512 & $3.55 \pm 0.01$ \\
\hline $87.5 \%$ & 1512 & $3.47 \pm 0.02$ \\
\hline Season at calving & & * \\
\hline Wet & 1728 & $3.54 \pm 0.01$ \\
\hline Dry & 1152 & $3.48 \pm 0.02$ \\
\hline $\mathbf{n}$ & & 2880 \\
\hline $\mathrm{R}^{2}$ & & 0.39 \\
\hline $\mathrm{CV} \%$ & & 15.77 \\
\hline Mean \pm sem & & $3.57 \pm 0.01$ \\
\hline
\end{tabular}

\section{Discussion}

Effect of calf rearing management and milking method on milk production

Restricted suckling of cows caused an increased SMP and TMP, and also improved annual milk yield and milk yield per day of calving interval in comparison to cows without suckling. These results are in agreement with reports by ALVAREZ et al. (1980a), LITTLE et al. (1991), and MARGERISON et al. (2002) and confirm the higher utilization of cows' milk potential when milking is combined with suckling. Restricted suckling utilizes residual milk, which is only marginally obtained in cows without restricted calf suckling. The increased milk yield over a long period must result from an increased rate of galactopoiesis. Suckling stimulates releasing of oxytocin, which affects the milk ejection (WELLNITZ et al., 1999; NAUMANN and FAHR, 2000). Suckling also stimulates the release of prolactin, adrenocorticotropin and somatotropin which is thought to maintain galactopoiesis in many species (TUCKER, 1985).

DODD and PHIPPS (1985) stressed the role of the strong milk ejection reflex for enabling the milker to obtain the maximum possible amount of milk and to leave only a minimum amount of residual milk. Milk ejection is induced by enhanced release of oxytocin from the pituitary gland in response to tactile stimulation such as suckling (GOREWIT and GASSMANN, 1985). Without pre-milking stimulation, milk flow is reduced or totally interrupted after removal of the cisternal milk until oxytocininduced milk ejection occurs (BRUCKMAIER and BLUM, 1996). Myoepithelial cells 
are sensitive to mechanical stimulation and the tap reflex, induced by the butting calf , may augment the action of oxytocin on these cells (FINDLAY and GROSVENOR, 1967). Milk ejection probably is most efficient when mechanical stimuli and oxytocin combine to affect the myoepithelial cells (GOODMAN and GROSVENOR, 1983; MIJIĆ et al., 2002).

The higher milk yield of machine-milked cows over their hand-milked herdmates may be explained by the longer duration of the hand-milking process and the effect of disturbances caused by the less uniform hand-milking process, which can cause a negative effect on milk let down. Because milk ejection is transitory, NAUMANN and FAHR (2000) suggested the maximum milk yield is obtained when milking is quick so as to fall within a short period of some hormonal effects. In the present study, actually we noticed that it took approximate between 5 and 8 minutes per each cow for one hand-milking and 3 to 6 minutes for machine-milking. The shorter milking time when using the machine-milking method may explain the yield advantage of machinemilking over hand-milking.

Shorter lactation lengths of cows with bucket rearing of calves as compared to cows with restricted suckling were also found in other reports (ALVAREZ et al., 1980a; UGARTE, 1991). UGARTE (1991) showed that the presence of a suckling stimulus over a longer period (six months) prolonged lactation length. The longer lactation length may relate to the higher persistency of milk production in cows managed under RS system over the BR system.

Effect of calf rearing management and milking method on udder health

The overall pattern of SCS during lactation is consistent with reports by FUNKE and SCHLOTE (1999) and EMANUELSON and PHILIPSSON (1984).

Cows exposed to BR management exhibited a highly significant $(p<0.001)$ higher SCS than suckled cows. During day 4-84 of lactation there was no case of mastitis in the RS group, while 3 cows of the BR treatment group exhibited a high SCS during this period. Thereafter, mastitis cases were found in both groups of calf rearing treatment groups with five in the BR but only two cases in the RS group. The lower SSC in RS cows may have been caused by the better evacuation of the udder through suckling which caused also a reduction in the number of pathogens and amount of the residual milk. These results are in agreement with ALVAREZ et al. (1980b), MEJIA et al. (1998), SAHN et al. (1997), and UGARTE (1991) who reported no incidence of mastitis in crossbred dairy cow during the calf suckling period. RASMUSSEN and LARSEN (1998) showed that suckling lowered also the number of esculin positive bacteria on the teat skin and, thus, improved the udder health condition.

The larger SCS of the machine-milked cows as compared to the hand-milking group in this study could be caused by the fact that the machine-milking process offers multiple opportunities for microorganisms to infect the udder. During milking, vacuum fluctuations in the claw head leads to milk moving between teat cups. If the cow being milked has one or more infected quarters, this process transfers pathogenic microorganisms to the surface of other teats. After a cow has been milked, the inner liner surface of the milking machine could carry microorganisms originating from the infected quarters which can be transferred to the next animal if the teat cups are not disinfected in between milking of cows.

Machine-milking can influence the exposure of the teat orifice and duct to pathogenic organisms. Machine-milking may lead to hyperkeratosis of the teat orifice, and may 
also lead to haemorrhagic blisters at the teat end, to teat chapping and lesion. Such skin abnormalities are readily colonized by pathogenic microbes, and may lead to intramammary infections. HAMANN and STANITZKE (1990) found that machinemilking caused a significant increase in thickness of the teats, which does not occur with hand-milking and calf suckling. Thirty minutes after milk withdrawal by suckling or hand-milking the teats returned to their pre-milking thickness, while the recovery time for machine milked was requires 1-2 hours (HAMANN, 1989).

Machine-milking may also cause trauma to the teat rendering it more susceptible to colonization and infection. Trauma to the mucous membranes lining the teat sinus may provide an environment favoring bacteria colonization or multiplication. Local pain may lead to neurohormonal responses which suppress immune function and increase the likelihood of disease. The effect of continued use of machine-milking on the cow's udder and teats cannot be underestimated.

The quarter position significantly $(\mathrm{p}<0.001)$ influenced the SCS of the cows (BALTAY, 2002). It was found that the quarter in the right rear position of the udder had the lowest score of 3.33, whereas the others had values ranging from 3.55 to 3.60. This may be caused by a "blind milking effect". It was observed in this study that the working position of the milkers during milking process in both hand-milking and machine-milking were on the right side of the cows. Quarter related SCS and mastitis cases are also reported by PEELER et al. (2003), however, without discussing differences between quarters.

Week of lactation (stage of lactation) also significantly $(\mathrm{p}<0.001)$ affected the SCS during weeks 2-36 of lactation. The alteration pattern of SCS was similar to the pattern of change of milk components, high SCS were found during the first weeks of lactation and again during late lactation (week 16-36). The shape of this curve indicated a possible effect of dilution, and can be described as the inverted milk production curve (KENNEDY et al., 1982; EMANUELSON and PERSSON, 1984; LAEVESN et al., 1997; NEUMANN and KRÜGER, 1999).

\section{Conclusions and recommendations}

The restricted calf suckling management in combination with milking has never been practised in any milk production system in Thailand. The results of this study indicate that strategies of dairy production with restricted suckling of crossbred HolsteinFriesian dairy cows can improve milk production performance of saleable milk, and increased lactation milk yield even though suckling ended on day 84 of lactation.

The restricted suckling system significantly improved SCS, and sustained the udder health during suckling period and this also had a carry over effect a few weeks after the end of calf suckling period.

The results obtained under Experiment-Station conditions already indicate the potential problem of machine milking, which under practical conditions in small farms could cause major udder health problems with highly significant financial consequences in terms of the productive life of a cow and treatment cost.

Restricted suckling is therefore a more appropriate and sustainable system for managing cows than the removal and artificial rearing of calves and, thus, can be highly recommended for smallholder farmers. The introduction of restricted suckling for crossbred dairy cows may require training of smallholders as they are not familiar with this production system. 
Machine milking has a clear advantage in cows with higher milk yields but it has a significant negative effect on udder health. Sustainable machine milking therefore requires extreme care and many smallholders in Thailand may benefit from staying with hand milking due to a lower technical demand and disease risk.

\section{References}

ALVAREZ, F.J.; SAUCEDO, G.; ARRIAGA, A.; PRESTON, T.R.:

Effect on milk production and calf performance of milking crossbred European/Zebu cattle in the absence or presence of calf, and of rearing their calves artificially. Trop. Anim. Prod. 5 (1980a), 25-37

ALVAREZ, F.J.; DE LEON, J.; AYALA, A.:

Milk production in the tropics: Milking with and without calf and with and without supplementation with AOAC: Lucaena leucocephala. Trop. Anim. Prod. 5 (1980b), 296-305

Dairy Products. In: Official Methods of the Association of Official Analytical Chemists. $14^{\text {th }}$ Edition. Williams, S. (Ed.). Association of Official Analytical Chemists Inc., Arlington, Virginia, USA. (1984), pp. 276-319

BALTAY, Z.:

Influence of time of day the milk and season on the somatic cell count under Hungarian conditions. Arch. Tierz., Dummerstorf 45 (2002) 4, 349-357

BRUCKMAIER, R.M.; BLUM, J.W.:

Simultaneous recording of oxytocin release, milk ejection and milk flow during milking of dairy cows with and without prestimulation. J. Dairy Res. 63 (1996), 201-208

CHANTALAKHANA, C.:

Dairy Enterprise Development and Milk Products in Thailand: Future Trend of Research and Development. Thai Research Fund. Bangkok. (Thai Edition) (1995), 96 pp.

DODD, F.H.; PHIPPS, R.H.:

Milking management and health. In : Milk Production in Developing Countries. SMITH, A. J. (Ed.). Proceeding of the conference held in Edinburgh from 2-6 April 1984. Centre for Tropical Veterinary Medicine. Edinburgh, UK. (1985), 258-272 pp.

EMANUELSON, U.; PERSSON, S.:

Studies on somatic cell counts in milk from Swedish dairy cows. II. Estimates of genetic parameters of monthly test day results. Acta Agri. Scand. 34 (1984), 45-52

FINDLAY, A.L.R.; GROSVENOR, C.E.:

A transient fall in pressure precedes the characteristic intramammary pressure rise following mechanical stimulation of the mammary gland. Proc.of the Soc. of Exp. Biol. and Med. 126 (1967), 637-640

FUNKE, U.; SCHLOTE, W.:

Vorläufige Ergebnisse von Detailerhebungen zur Eutergesundheit. Paper presented at the "70 Sitzung des Ausschusses für genetisch -statistisch Methoden in der Tierzucht der Deutschen. Gesellschaft für Züchtungskunde", 27-30 March 1999 at Clausberg of Eisenach. (1999) (Personal communication)

GOODMAN, G.T.; GROSVENOR, C.E.:

Neuroendocrine control of the milk ejection reflex. J. Dairy Sci. 66 (1983), 2226-2235

GOODWIN, J.; SPELMAN, S.L.:

Genetic evaluation for somatic cell score. Guernsey Breeders J., 30, (2) (1994)

GOREWIT, R.C.; GASSMAN, K.B.:

Effect of duration of udder stimulation on milking dynamics and oxytocin release. J. Dairy Sci. 68 (1985), 1813-1818

HAMANN, J.:

Machine milking and new infection risk. Proc. Int. Conf. Mastitis, St.Georgen, Kärnten, Austria. (1989), 113-122 pp.

HAMANN, J.; STANITZKE, U.:

Studies on pathogenesis of bovine mastitis by comparison of milking conditions as calf suckling, hand milking and machine milking: reactions of the teat tissue. Milchwissenschaft 45 (1990), 632-637

KENNEDY, B.W.; SETHAR, M.S.; MOXLEY, J.E.; DOWNEY, B.R.:

Heritability of somatic cell count and its relationship with milk yield and composition in Holsteins. J. Dairy Sci. 65 (1982), 843-852

LAEVENS, H.; DELUYKER, H.; SCHUKKEN, Y.H. ; DE MEULEMEESTER, L.; VANDERMEERSCH, R.;

DE MUELENAERE, E.; DE KRUIF, A.:

Influence of parity and stage of lactation on the somatic cell count in bacteriologically negative dairy cows. J. Dairy Sci. 80 (1997) 12, 3219-3226

LITTLE, D.A.; ANDERSON, F.M.; DURKIN, J.W.: 
Influence of partial suckling of crossbred dairy cows on milk offtake and calf growth in the Ethiopia highlands. Trop. Anim. Health and Prod. 23 (1991), 108-114

MARGERISON, J.K.; PRESTON, T.R.; PHILLIPS, C.J.:

Restricted suckling of tropical dairy cows by their own calf or other cows' calves. J. Anim. Sci. 80 (2002) 6, 1663-1670

MEJIA, C.E.; PRESTON, T.R.; FAJERSSON, P.:

Effect of restricted suckling versus artificial rearing on milk production, calf performance and reproductive efficiency of dual purpose Mpwapwa cattle in a semi-arid climate. Livest. Res. Rural Dev. 10 (1) (1998) (available at www.fao.org/ WAICENT/FAOINFO/AGRICULT/AGA/AGAP/FRG/ LRRD/)

MIJIĆ, P.; KNEŽEVIĆ, I.; DOMAĆINOVIĆ, M.; BABAN, M.; KRALIK, D.:

Distribution of milk flow in Holstein Friesian and Fleckvieh cows in Croatia. Arch. Tierz., Dummerstorf 45 (2002) 4, 341-348

NAUMANN, I.; FAHR, R.-D.:

Untersuchungen zum Milchfluss aus Eutervierteln. Arch. Tierz., Dummerstorf 43 (2000) 5, 431-440

NEUMANN, A.; KRÜGER, M.:

Effect of lactation state (1st-20th week of lactation) on dynamics of C-reactive protein (CRP) in initial quarter milk samples in relation to somatic cell count, lactose content and blood serum CRP levels.

NRC: Tierärztliche Praxis, Ausgabe G, Grosstiere Nutztiere 27 (1999) 2, 110-113

Nutrient Requirements of Dairy Cattle (6 $6^{\text {th }}$ Ed.). National Academy Press, Washington D.C., USA (1989)

PEELER, E.J.; GREEN, M.J.; FITZPATRICK, J.L.; GREEN, L.E.:

The association between quarter somatic-cell counts and clinical mastitis in three British dairy herds. Prev. Vet. Med. 59 (2003) 3, 169-180

POLPAK, S.:

Management to improve the problem reproduction of dairy cattle in Northeastern Thailand. Animal Health Newsletter. Animal Disease Research and Diagnosis Center /Northeastern Region) (Thai edition), 5 (4) (1994a), 40-42

POLPAK, S.:

Management problem of dairy cattle in Northeastern Thailand. Animal Health Newsletter. Animal Disease Research and Diagnosis Center (Northeastern Region) (Thain Edition). 5 (1) (1994b), 6-9

RASMUSSEN, M.D.; LARSEN H.D.:

The effect of post milking teat dip and suckling on teat skin condition, bacterial colonisation, and udder health. Acta Vet. Scand. 39 (1998) 4, 443-452

SAHN, M.V.; PRESTON, T.R.; LY, L.V.:

Effect of restricted suckling versus artificial rearing on performance and fertility of crossbred F1 (Holstein-Friesian x Local) cows and calves in Vietnam. Livest. Res. Rur. Dev. 9 (4) (1997)

(available at www.fao.org/ WAICENT/FAOINFO/AGRICULT/AGA/AGAP/FRG/LRRD/)

SAS:

SAS users manual. Statistical Analysis System, Cary, NC (1998)

TUCKER, H.A.:

Endocrine and neural control of the mammary gland. In : Lactation. First Edition. LARSON, B.L. (Ed.).

Iowa State University Press, Ames, Iowa, USA. (1985), 39-79 pp.

UGARTE, J.:

Restricted suckling in dual purpose systems. In : Feeding Dairy Cows in the Tropics. FAO Animal Production Health paper No. 86. Proceeding of the FAO Expert Consultation held in Bangkok, Thailand 7-11 July 1989. Speedy, A. and R. SANSOUCY (Eds). Rome, Italy. (1991),199-207 pp.

VINTHER, K.:

Productive Performance of the Dairy Herd and Evaluation of the Breeding Plan at The Thai-Danish Dairy Farm. Report to the Dairy Farming Promotion Organization of Thailand, Ministry of Agriculture and Cooperatives. (1974), pp. 85

WELLNITZ, O.; BRUCKMAIER, R.M.; BLUM, J.W.:

Milk ejection and milk removal of single quarters in high yielding dairy cows. Milchwissenschaft 54 (1999) 6, 303-306

Received: 2004-02-26

Accepted: 2004-05-17

Corresponding author

Prof. Dr. KURT J. PETERS

Department of Animal Breeding in the Tropics and Subtropics, Faculty of Agriculture and

Horticulture, Humboldt University-Berlin,

Philippstr. 13, Haus 9

D-10115 Berlin / Germany 